\title{
Colony versus population variation in susceptibility and resistance to dark spot syndrome in the Caribbean coral Siderastrea siderea
}

\author{
Deborah J. Gochfeld ${ }^{1, *}$, Julie B. Olson ${ }^{2}$, Marc Slattery ${ }^{1,3}$ \\ ${ }^{1}$ National Center for Natural Products Research, PO Box 1848, University of Mississippi, University, Mississippi 38677, USA \\ ${ }^{2}$ Department of Biological Sciences, PO Box 870344, University of Alabama, Tuscaloosa, Alabama 35487, USA \\ ${ }^{3}$ Department of Pharmacognosy, PO Box 1848, University of Mississippi, University, Mississippi 38677, USA
}

\begin{abstract}
Scleractinian corals appear to be increasingly susceptible to pathogenic diseases, yet it is poorly understood why certain individuals, populations or species are more susceptible to diseases than others. Clearly an understanding of mechanisms of disease resistance in corals is essential to our understanding of patterns of disease incidence and virulence; this work must begin by examining the colony and population levels of organization. The Caribbean coral Siderastrea siderea exhibits variability in susceptibility to dark spot syndrome (DSS), a disease of unknown origin that can result in tissue necrosis. On the reef scale, variability in DSS prevalence in S. siderea occurred through time, but was not correlated with site, seawater temperature or depth. We monitored colonies of S. siderea affected by DSS, as well as their nearest neighbor controls, for 2 years in the Bahamas and found a marked decline in extent of DSS infection in October of both years. A preliminary survey of antimicrobial activity in $S$. siderea indicated selective activity against certain ecologically relevant bacteria. To assess whether changes in chemical defenses were responsible for the observed temporal variability in DSS prevalence, we sampled $S$. siderea for qualitative and quantitative analysis of chemical variability between resistant and susceptible colonies of $S$. siderea. These data suggest that phenotypic plasticity in antimicrobial activity may impact microbial settlement and/or survival.
\end{abstract}

KEY WORDS: Coral disease · Siderastrea siderea $\cdot$ Caribbean $\cdot$ Disease prevalence $\cdot$ Disease resistance $\cdot$ Chemical defense $\cdot$ Antimicrobial activity $\cdot$ Dark spot syndrome

\section{INTRODUCTION}

In the marine environment, epidemic outbreaks of previously unknown diseases have been reported with alarming frequency over the past 3 decades (Harvell et al. 1999). Among scleractinian corals, recent years have seen both an increased prevalence of diseases and an increased number of species infected (Goreau et al. 1998, Richardson 1998, Green \& Bruckner 2000, Porter et al. 2001, Rosenberg \& Loya 2004). Depending on the spatial scale examined, either the population- or community-level effects of these diseases may be significant (Gladfelter 1982, Lessios 1988, Edmunds 1991, Porter \& Meier 1992, Peters 1997). A number of these diseases have been shown to cause either tissue necrosis (i.e. death of individual polyps) or mortality of the entire coral colony (Rosenberg \& Loya 2004). Of the many coral diseases now recognized (actual number of diseases depends on the reference cited), etiologic agents have been identified for only a few: aspergillosis (Aspergillus sydowii; Geiser et al. 1998, reviewed by Smith \& Weil 2004), black band disease (BBD) (microbial consortium; reviewed by Richardson 2004), plague type II (Aurantimonas coralicida; Richardson et al. 1998, Denner et al. 2003), white pox (Serratia marcescens; Patterson et al. 2002), bacterial bleaching (Vibrio shiloi $[=V$. shilonii $]$; Kushmaro et al. 2001) and tissue lysis (V. coralliilyticus; Ben-Haim et al. 2003, 
Rozenblat \& Rosenberg 2004). The sources of these pathogens in the marine environment are not entirely clear, but anthropogenic influences are thought to be important. For example, S. marcescens, a common human fecal enterobacterium (Patterson et al. 2002), may enter the ocean from water treatment plants (Sutherland \& Ritchie 2004, Sutherland et al. 2004). The common soil fungus A. sydowii may be transported during African dust storms and deposited on Caribbean coral reefs, where it becomes pathogenic to sea fans (Shinn et al. 2000, Garrison et al. 2003).

The emergence of new marine diseases and the increased vulnerability of corals to diseases are believed to have arisen from range shifts of known pathogens (Harvell et al. 1999), the evolution of more virulent pathogens, and/or compromised host defenses (Hayes \& Goreau 1998, Carey 2000). Several researchers have suggested that development of pathogenesis in coral tissues depends on lowered coral resistance resulting from anthropogenic or environmental stress (Peters 1993, Geiser et al. 1998, Harvell et al. 1999, 2002, Carey 2000). Indeed, there is some evidence that the microbial consortium responsible for $\mathrm{BBD}$ is more prevalent on corals subject to anthropogenic stress (Taylor 1983, Antonius 1985, Kuta \& Richardson 2002), and correlative studies suggest that the incidence of certain diseases is higher on reefs exposed to anthropogenic influences (Green \& Bruckner 2000, Sutherland et al. 2004). Temperature stress, due to increased frequency and severity of El Niño Southern Oscillation (ENSO) events and global warming, has clearly taken a toll on corals in terms of stress and mortality due to bleaching (Harvell et al. 1999, 2002, Rosenberg \& Ben-Haim 2002). There is evidence that host resistance and/or pathogen virulence are also impacted either directly or indirectly by these stresses (Toren et al. 1998, Rozenblat \& Rosenberg 2004, Sutherland et al. 2004). Stress has been demonstrated to reduce production (Cronin \& Hay 1996, Slattery 1999) or efficacy (Alker et al. 2001) of chemical defenses (see below), which might account for this increased susceptibility to infectious microorganisms that might otherwise be deterred by antimicrobial compounds. Although many researchers are presently monitoring coral reefs for disease incidence, there is little known about why certain individuals, populations or species are more susceptible to disease than others.

Chemical defenses are well documented in marine invertebrates (see reviews by Paul 1992, Pawlik 1993, McClintock \& Baker 2001), and whereas several researchers have demonstrated antimicrobial activities for these chemical defenses (e.g. Sammarco \& Coll 1992, Walls et al. 1993, Wahl et al. 1994, Slattery et al. 1997), few studies have considered them as potential sources of protection from disease (note their absence in a review by Hayes \& Goreau 1998, but inclusion in a later review by Sutherland et al. 2004). Many gorgonians have antimicrobial activity (Jensen et al. 1996), and Kim et al. (2000a,b) found that crude extracts from several Caribbean gorgonian species inhibited spore germination of Aspergillus sydowii. However, only a few studies have identified pure compounds with antimicrobial activity (Gram et al. 1996, Slattery 1999). Whereas antimicrobial chemical defenses are widespread in soft-bodied marine invertebrates, including soft corals (recently reviewed in Kelman 2004), there have been very few investigations of chemical defenses in scleractinian corals. Gochfeld (1997) demonstrated chemical defenses against predatory fish in the Hawaiian coral Porites compressa and in several Caribbean corals (D. J. Gochfeld unpubl.). In a preliminary survey of Australian corals, Koh (1997) identified variable antimicrobial activity of crude extracts against several marine microbes with no known pathogenic effects on corals. Kelman (2004) found minimal antimicrobial activity of Red Sea corals against marine bacteria. It is unclear whether antimicrobial metabolites in corals are constitutive defenses that are always present (i.e. genetically fixed) or inducible defenses (i.e. 'those defenses that are fabricated when needed and dismantled when not needed'; Karban \& Baldwin 1997, Tollrian \& Harvell 1999) produced in direct response to pathogen assault.

Dark spot syndrome (DSS), also called dark spots disease, was first described in the 1990s (GarzonFerreira \& Gil 1998) and has since been observed throughout the Caribbean (Weil et al. 2000, Borger 2003, Gil-Agudelo et al. 2004, Weil 2004). Because DSS was described only recently, relatively little is known about this disease. DSS is manifested by darkened areas on otherwise seemingly healthy coral tissue. These purple to brown areas may gradually enlarge and a depression may form in the coral skeleton, with subsequent necrosis and invasion by algae. DSS may persist for long periods, or the infection may disappear without any evident damage. DSS affects several species of scleractinian corals (Weil et al. 2000, GarzonFerreira et al. 2001, Gil-Agudelo \& Garzon-Ferreira 2001, Weil 2004) but at our study sites in the Bahamas, it most frequently affects the massive coral Siderastrea siderea. In fact, $S$. siderea appears to be among the most susceptible species to several coral diseases (Porter et al. 2001, Borger 2003, Weil 2004). Although DSS may progress slowly and cause low levels of coral necrosis, its high incidence and prevalence on Caribbean reefs and the fact that it affects important reef building species suggest that this disease may be important to overall coral reef health. DSS is known to vary on both temporal and spatial scales. Increasing 
water temperature and decreasing depth are the main environmental correlates identified with this disease (Gil-Agudelo \& Garzón-Ferreira 2001). To date, no etiologic agent has been conclusively identified as the cause of DSS, although there are differences in microbial communities from healthy and infected colonies (Gil-Agudelo et al. 2004, D. J. Gochfeld \& J. B. Olson unpubl.). Our goal was to further investigate temporal and spatial variability in DSS at the reef scale and also, to expand beyond previous work, at the individual (colony-level) scale. Further, we planned to examine the mechanisms behind the patterns we observed. This study was conducted from the Caribbean Marine Research Center (CMRC) on Lee Stocking Island (LSI), Exuma Cays, Bahamas. The Exuma Cays are relatively pristine, compared to other Caribbean regions, as the area consists primarily of uninhabited low coral islands with no nearby sources of anthropogenic stressors, such as pollution, sewage or sedimentation.

\section{MATERIALS AND METHODS}

Prevalence and seasonality of disease at reef and colony scales. Surveys of DSS prevalence were conducted at 5 reef sites within approximately $10 \mathrm{~km}$ of LSI (Fig. 1). Two of these are fore-reef sites (Bock Wall, Whitehorse) and 3 are tidally influenced back-reef sites (Washing Machine, North Norman's, Rainbow Gardens). Bock Wall is the flat upper surface of a steep drop-off at $27 \mathrm{~m}$, where Siderastrea siderea is one of the most abundant corals. Whitehorse is a large bowlshaped depression and surveys were conducted both in the base of the bowl $(14 \mathrm{~m})$ and around its rim $(7 \mathrm{~m})$. Washing Machine reef slopes down to a tidal channel and surveys were conducted within the channel $(14 \mathrm{~m})$ and along its slope $(5 \mathrm{~m})$. North Norman's and Rainbow Gardens are shallow $(5 \mathrm{~m})$, tidally influenced back-reef areas.

Since the reef sites were of different shapes and sizes, neither a line nor circular transect was appropriate at all sites. Instead, during each visit, surveys were conducted by swimming in a back and forth search pattern over as much of the site as possible in a $10 \mathrm{~min}$ period, counting all colonies of Siderastrea siderea observed, and noting whether DSS (and other diseases) was present or not. Subsequent surveys covered approximately the same area as previous surveys at that site and included approximately the same number of colonies. For this analysis, every ramet was considered a separate coral colony, as described by GilAgudelo \& Garzon-Ferreira (2001). Surveys were conducted approximately seasonally, in May, August and October 2002, January, August and October 2003, and January and July 2004. DSS prevalence data (defined as $S$. siderea with DSS:total number of $S$. siderea) were arcsin transformed and 2-way ANOVAs were used to determine whether DSS prevalence differed by date and either site or depth. Pair-wise, a posteriori comparisons were used to determine which time periods were significantly different.

In addition to the reef scale, we also measured DSS cover on individual colonies. In May 2002, we marked 9 colonies (4 at North Norman's and 5 at Rainbow Gardens) of Siderastrea siderea that were affected by DSS at that time. We also located and marked their nearest unaffected neighboring $S$. siderea. Initial colony sizes were $540.0 \pm 306.26 \mathrm{~cm}^{2}$ for the diseased colonies and $682.29 \pm 854.96 \mathrm{~cm}^{2}$ for the control colonies. During each survey period (listed above), digital photographs were taken of each colony using a $0.25 \mathrm{~m}^{2}$ quadrat to standardize for distance and orientation. Two images, one containing all of the live coral area and the other containing only the healthy coral tissue, were produced on a Macintosh G4 computer using the public domain NIH Image program (developed at the U.S.

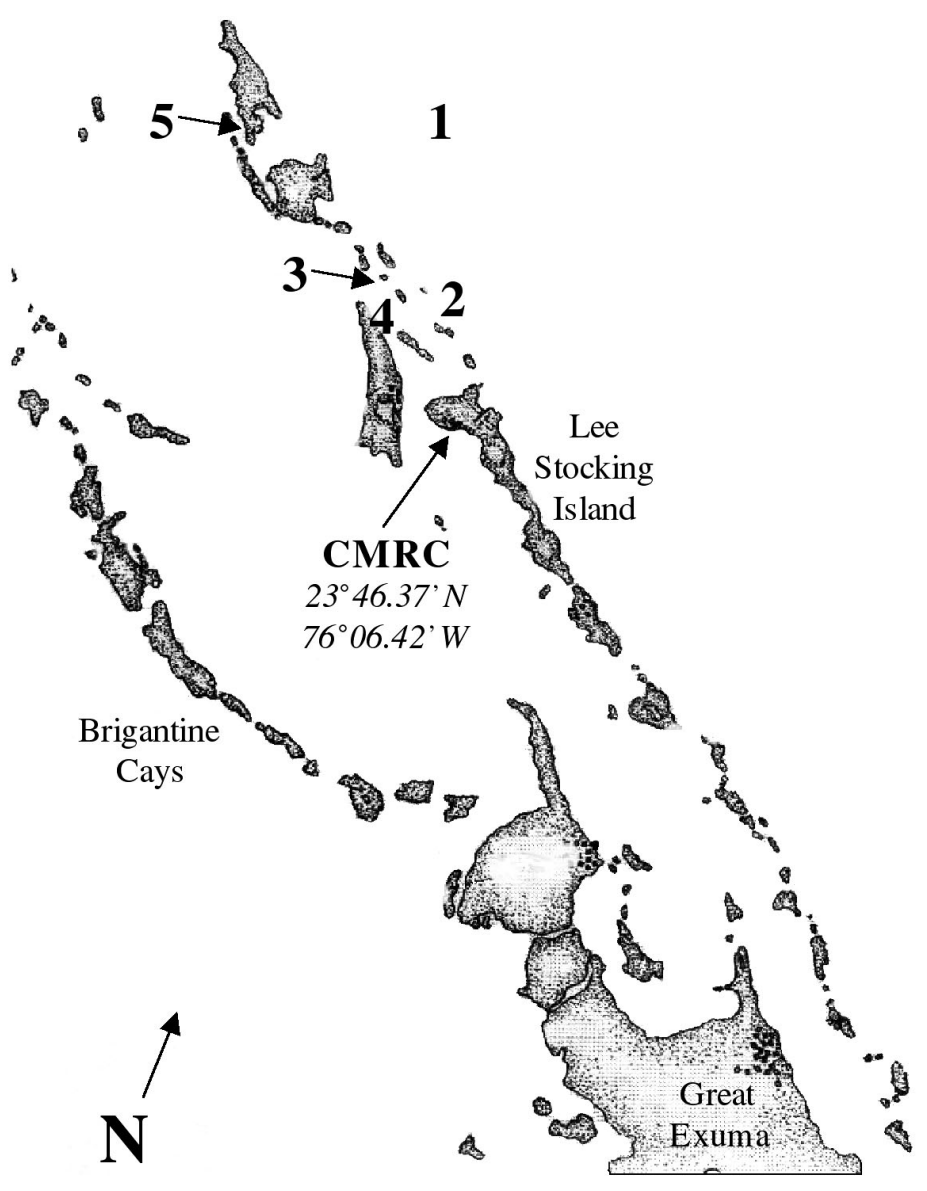

Fig. 1. Study sites near the Caribbean Marine Research Center (CMRC), Lee Stocking Island, Exuma Cays, Bahamas. $1=$ Bock Wall, 2 = Whitehorse, 3 = Rainbow Gardens, $4=$ North Norman's, $5=$ Washing Machine 
National Institutes of Health and available on the Internet at http://rsb.info.nih.gov/nih-image/). The percent cover of DSS on each colony at each point in time was calculated by subtracting the area of healthy coral tissue from the total live coral tissue using ImagePro ${ }^{\circledR}$ Plus Version 4.5 (Media Cybernetics). A repeated measures ANOVA was used to compare percent cover of DSS over time by reef and colony condition (initially healthy or diseased).

Using these same images, we determined whether DSS consistently affected the same tissue area over time. For this analysis, we used images from August 2002, August 2003 and July 2004, the summer months when DSS cover tended to be highest. For 8 of our monitored colonies, images were standardized for size and orientation using Image-Pro ${ }^{\circledR}$ Plus, and a grid was placed over each image such that the points on the grid were in the same location on each image. Each point was then scored as diseased (D) or healthy $(\mathrm{H})$. Counts were then made of how many points were $\mathrm{D}$ or $\mathrm{H}$ on all 3 dates and every combination of dates (i.e. $\mathrm{HHH}$, HHD, HDH, HDD, DHH, DHD, DDH, DDD). Chisquared tests were used to test 2 hypotheses: (1) a point that is healthy at time 0 is equally likely to remain healthy or become diseased (HHH vs. all other categories beginning with $\mathrm{H}$ ); and (2) a point that is diseased at time 0 is equally likely to be diseased or become healthy (DHH vs. all other categories beginning with D).

In August 2003 we began monitoring additional colonies at 4 of our sites (Bock Wall was excluded due to the limited bottom time possible at $27 \mathrm{~m}$ ), including both depths at Whitehorse and Washing Machine. We deployed rebar stakes to mark the ends of a $20 \mathrm{~m}$ transect and recorded the transect coordinates for each Siderastrea siderea colony within $1 \mathrm{~m}$ on either side of the transect line. The size (length $\times$ width of living tissue in $\mathrm{mm}$ ) and relative health status ( $0=$ healthy, 1 to 4 = light to moderate DSS, 5 = extensive DSS) of these colonies were noted in August 2003 and on each subsequent sampling date. Since relative health status is a qualitative value, Kendall rank correlations were used to determine if there was a relationship between relative health status and colony size. These analyses were performed on data from 71 colonies $\left(0.25-5400 \mathrm{~cm}^{2}\right)$ on each sampling date from August 2003 to July 2004. Only colonies that were found on all sampling dates were used in the analysis and, although the presence of other types of disease was recorded, those data were omitted from this analysis.

Environmental correlates of disease. Seawater temperature measurements were made at each of the reef sites from August 2003 to July 2004. Temperatures were measured using StowAway ${ }^{\circledR}$ Tidbit $^{\mathrm{TM}}$ Temperature Loggers (Onset Computer Corp.), which were placed in small vexar cages and cable tied to rebar stakes on the reef at the same depths at which disease surveys were conducted. Temperatures were logged at 10 min intervals and loggers were downloaded during each survey period and returned to the reef. DSS prevalence data were arcsin transformed and ANCOVA was used to examine the effects of date and temperature on DSS prevalence at the 5 survey sites from August 2003 to July 2004. For this analysis, mean temperature for $10 \mathrm{~d}$ surrounding the actual survey date for each site was used as the covariance factor.

In August 2003, a nutrient enrichment experiment was conducted in the laboratory at CMRC. Ten small $(\bar{x}=5.52 \mathrm{~cm}$ diam. $)$ colonies of Siderastrea siderea were collected from North Norman's reef, measured, photographed and placed in plastic aquaria with flowthrough seawater. After $2.5 \mathrm{~h}$, the flow-through seawater was removed and air bubblers were added. Five colonies were exposed to a nutrient enrichment treatment consisting of a nylon stocking containing $25 \mathrm{~g}$ of Osmocote $^{\circledR}$ (Scotts) 18-6-12 time-release fertilizer, while the 5 controls received the same treatment without the fertilizer. The treatment lasted for $6 \mathrm{~d}$, and the tanks were flushed with flow-through seawater for $1 \mathrm{~h}$ each day. At the end of the experiment, we used Woolsey/Z-Spar Splash Zone epoxy (Kop-Coat) to attach the corals to $\mathrm{PVC}$ racks which were returned to North Norman's reef, and their condition was followed for 5 mo (see below). Chi-squared tests based on the null hypothesis that disease would not be affected by nutrient treatment were used to test for significant disease induction in the control and nutrient-enriched corals.

A common garden transplant experiment was conducted to determine whether susceptibility to DSS differed by site of origin. In August 2003, 5 healthy colonies of Siderastrea siderea were collected from each of our 5 survey sites (for Whitehorse and Washing Machine, corals were collected from the shallow depths) and transported to the laboratory at CMRC. The colonies were measured, photographed, and attached to PVC racks, along with the treated and control colonies from the nutrient enrichment experiment (see above). Each rack was transported in seawater to North Norman's reef $(5 \mathrm{~m})$ and attached to a cinder block using cable ties. The condition of these corals was monitored over time and the transplant experiment was retrieved after $5 \mathrm{mo}$, in January 2004. All colonies were then returned to the lab, measured, photographed, examined for DSS presence and frozen for future chemical analysis. Chisquared tests based on the null hypothesis that disease would not be affected by site of origin were used to test for significant disease induction in the 5 treatment groups. 
Antimicrobial activity and chemical variability in Siderastrea siderea. Small pieces of $S$. siderea were collected from shallow $(<15 \mathrm{~m})$ reef sites near CMRC. Small (approx. $5 \mathrm{~cm}^{2}$ ) pieces of coral were carefully collected from 5 healthy colonies and pooled to provide ample material for bioassays. Corals were immediately extracted in a solution of 1:1 methanol:methylene chloride (MeOH:DCM), which was replaced daily for $3 \mathrm{~d}$ until the coral was exhaustively extracted, and the extract was then concentrated under vacuum.

For analyses to be ecologically relevant, they need to be performed using natural or near-natural concentrations of extracts. Therefore, it was necessary to quantify the amount of coral tissue extracted. The paraffin wax method (Gochfeld 1991) was used to measure tissue surface area and this was multiplied by an approximate tissue depth measured in coral cross sections to calculate tissue volume. Extracts were then redissolved in an equivalent volume of $\mathrm{MeOH}$ :DCM to produce a natural volume of extract per unit coral tissue.

Microbial cultures were obtained by vigorously swabbing $2 \mathrm{~cm}^{2}$ sections of healthy tissue from coral colonies using cotton-tipped Culturette ${ }^{\circledR}$ applicators. For transport to the University of Mississippi (UM), the swab tip was aseptically transferred to a sterile 1-dram vial containing $2 \mathrm{ml}$ sterile seawater (SSW). The vials containing swab tips were vortexed for 1 min and the tips removed from the resulting microbial suspension, which were serially diluted at least 4 -fold using SSW (Button et al. 1993, Olson et al. 2000, Slattery et al. 2001). Triplicate $25 \mu \mathrm{l}$ aliquots from each microbial suspension were plated onto marine agar. Media plates were cultured up to $14 \mathrm{~d}$ at room temperature $\left(25^{\circ} \mathrm{C}\right)$ and all colony-forming units were isolated as individual strains for assay purposes. These strains were also cryopreserved at $-80^{\circ} \mathrm{C}$ in glycerol-amended SSW for future manipulation and identification.

To test for antimicrobial activity, the disc susceptibility assay was used. Briefly, extracts from Siderastrea siderea were inoculated onto filter discs (6 mm diam.), which were placed on actively growing monocultures of the microbe of interest. The presence of a microbialfree zone surrounding the disc after $48 \mathrm{~h}$, as compared to control discs that contained a carrier solvent only, was interpreted as evidence of antimicrobial activity. The coral extracts were tested against 4 gram-positive bacterial strains isolated from the surfaces of Bahamian corals. A 1-way ANOVA was performed to test for differences in zones of inhibition against the 4 bacterial strains tested.

To assess the temporal variability in chemical defenses of Siderastrea siderea, and to determine whether these differed with disease state, we collected small cores of tissues over time. Beginning in October 2002, we removed a small core of 'healthy' and 'dis- eased' tissue from each of the diseased colonies that we were monitoring. At each sampling period, our 'diseased' cores were taken from an area of active infection or, if DSS was not currently present, we used our digital images to identify an area of tissue that had been previously affected by DSS. For the 'healthy' cores, we chose areas that had not been affected by DSS since our monitoring began. We also collected a single core from the nearest neighbor control corals at each sampling period. Cores were collected by using a $1.7 \mathrm{~cm}$ diam. steel tube to score an area, and then chiseling out that core to a depth of 1 to $2 \mathrm{~mm}$. In almost every case, tissue had completely healed over the coring scars by the next sampling period. Cores were placed in labeled whirlpac bags in the field. Upon return to the lab, water was poured off and the cores were frozen for transport to UM.

Cores were extracted twice using Millipore ${ }^{\circledR}$ water and filtered. This water extract was lyophilized and weighed. The cores were then lyophilized to remove all remaining water and were then extracted twice with 1:1 MeOH:DCM. This organic extract was also dried and weighed. Preliminary analyses focused on the organic extracts from cores collected from the North Norman's corals in October 2002, January 2003 and August 2003. The organic extracts were solubilized to $10 \mathrm{mg} \mathrm{ml}^{-1}$ in acetonitrile and each sample was injected onto a Waters ${ }^{\circledR}$ Alliance 2695 High Performance Liquid Chromatography (HPLC) system (Symmetry C18 $5 \mu \mathrm{m}$ column; $21 \times 30$ mm; $25 \%$ acetonitrile to water using a linear gradient) interfaced with a Waters ${ }^{\circledR}$ Thermabeam Mass Detector for chemical fingerprinting. Effects of date and coral condition on arcsin transformed percent of peak area were determined using a multivariate analysis of variance (MANOVA) for the 4 major components of extracts.

\section{RESULTS}

\section{Prevalence and seasonality of disease at reef and colony scales}

In our reef surveys, DSS prevalence varied significantly over time (2-way ANOVA: MS $=0.055, F=$ $3.142, \mathrm{p}=0.03)$, but not by site (MS $=0.015, F=0.867$, $p=0.509$ ). When compared by date and depth, DSS prevalence also varied significantly over time (2-way ANOVA: $\mathrm{MS}=0.052, F=2.827, \mathrm{p}=0.021$ ), but not by depth (MS $=0.030, F=1.666, \mathrm{p}=0.205)$, and the date $\times$ depth interaction was nearly significant $(\mathrm{MS}=0.136$, $F=1.996, \mathrm{p}=0.054$ ). Pair-wise comparisons indicated significant peaks in DSS prevalence in August 2002 and significant declines in October 2002 and 2003 (Fig. 2). 


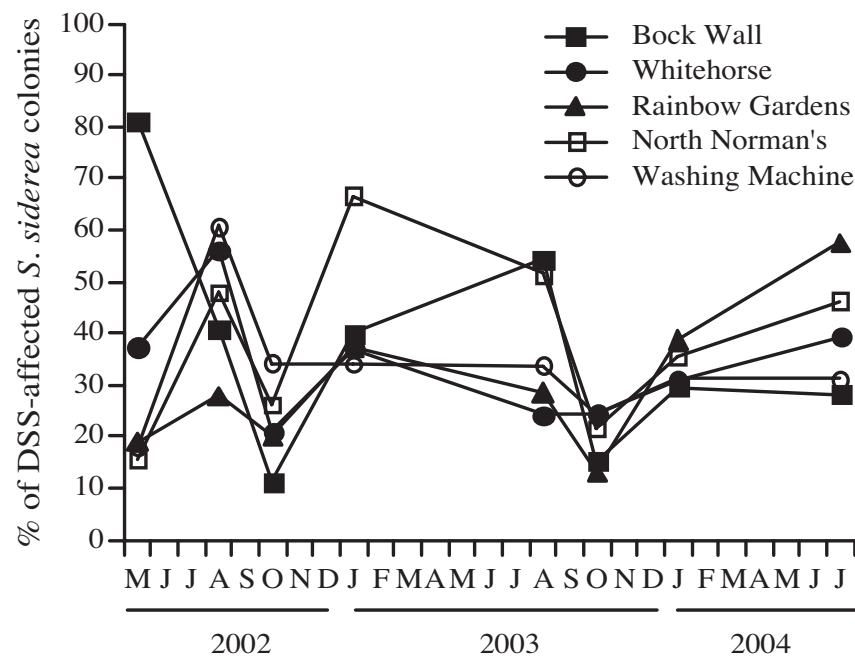

Fig. 2. Siderastrea siderea. Temporal and spatial variation in dark spot syndrome (DSS) prevalence (\% of affected colonies) of populations at 5 study sites from May 2002 to July 2004. For Whitehorse and Washing Machine, values from shallow and deep surveys have been combined

In May 2002, when we first marked our monitored colonies, there was no significant effect of reef (North Norman's vs. Rainbow Gardens) on percent cover of DSS on the diseased colonies (unpaired $t$-test: $t=$ $0.842, \mathrm{df}=7, \mathrm{p}=0.428$ ) and all control colonies on both reefs had zero percent cover of DSS. Therefore, we pooled all of the colonies into 1 analysis. However, a repeated measures ANOVA on the percent cover of DSS on all of the marked colonies from May 2002 to July 2004 (Figs. 3 \& 4) indicated a significant effect of date $(\mathrm{MS}=92.567, F=3.166, \mathrm{p}=0.005)$, coral condition (diseased vs. control; $\mathrm{MS}=3384.239, F=115.738, \mathrm{p}<$ $0.0001)$, and reef $(\mathrm{MS}=387.839, F=13.264, \mathrm{p}=$

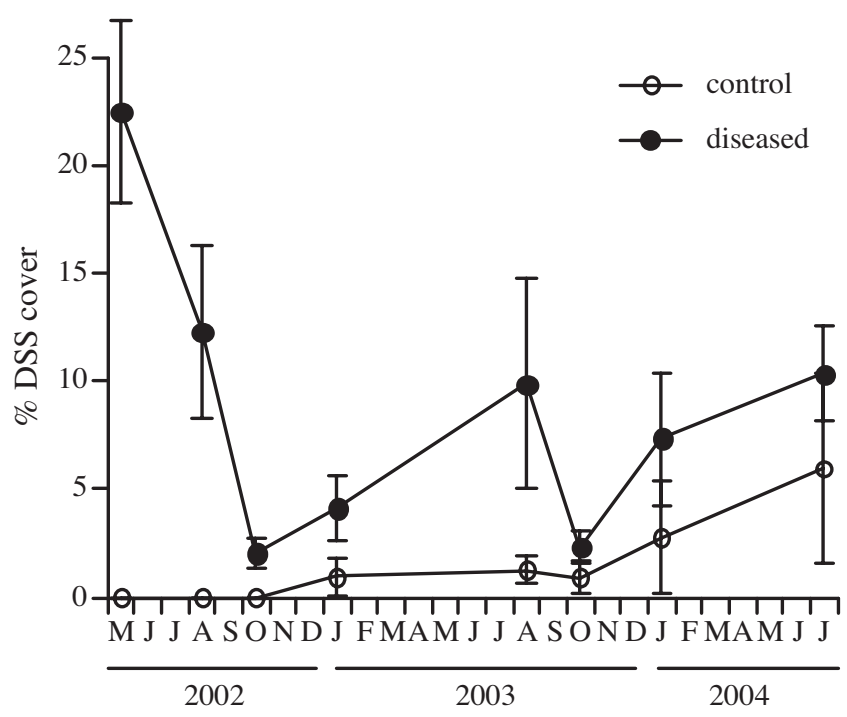

Fig. 3. Siderastrea siderea. Percent cover of DSS on marked control and diseased colonies from May 2002 to July 2004
0.0004), as well as significant interaction effects (date $\times$ condition: $p=0.003$; condition $\times$ reef: $p=0.019)$. No mortality of our monitored colonies was observed, although small areas of necrosis were noted.

For 5 of our 8 Siderastrea siderea colonies, a specific point that was healthy in August 2002 was equally likely to be healthy in both August 2003 and July 2004 as to become diseased on one or both of those dates (Fig. 5; chi-squared tests, $\mathrm{p}>0.05$ ); however, for 3 colonies, it was significantly more likely to remain healthy through all 3 dates (ratios of $\mathrm{HHH}$ to $\mathrm{HHD}+$ $\mathrm{HDH}+\mathrm{HDD}=24,6.5$ and 3.15; $\mathrm{p}<0.001, \mathrm{p}<0.001$, $\mathrm{p}=0.0053$, respectively). For all colonies, points that were diseased in August 2002 were equally likely to be diseased on one or more subsequent date as to become and remain healthy ( $p>0.05)$. Only $1.91 \pm 2.34 \%$ of points were diseased on all 3 dates.

There was no significant effect of site or depth on colony size or relative health status (Kruskal Wallis: $\mathrm{p}=$ 0.733 for site, $p=0.178$ for depth), and therefore, observations on colonies from all sites were pooled for each sampling date. Colony size was not significantly correlated with relative health status on any of the sampling dates (Kendall rank correlation: $p>0.05$ for all 4 dates), and overall, larger colonies (>100 $\left.\mathrm{cm}^{2}\right)$ were not significantly more likely to be affected by DSS than smaller colonies $\left(\leq 100 \mathrm{~cm}^{2}\right.$; chi-squared test: $\left.\chi^{2}=0.962, \mathrm{df}=1, \mathrm{p}=0.927\right)$.

\section{Environmental correlates of disease}

Mean seawater temperature on the study sites peaked in September to October prior to beginning its decline in late October, reaching a minimum in March (Fig. 6). Percent DSS cover on the marked diseased colonies was not correlated with mean seawater temperature (Kendall rank correlation: $p=0.2526$ ). DSS prevalence at the 5 survey sites varied significantly with date from August 2003 to July 2004 (ANCOVA: $\mathrm{MS}=0.053, F=5.240, \mathrm{p}=0.0153)$, but not with mean seawater temperature at those sites $(\mathrm{MS}=0.004, F=$ $0.613, \mathrm{p}=0.449$ ), although there was a significant date $\times$ temperature interaction due to the annual seawater temperature cycle (MS $=0.035, F=5.262, \mathrm{p}=0.0151$ ).

The nutrient enrichment treatment caused almost immediate bleaching of all 5 colonies in the laboratory, whereas the control corals did not bleach. In October 2003, 2 mo after the colonies were transplanted to North Norman's, all transplanted colonies, as well as many colonies at all of the survey sites, exhibited signs of bleaching. When the transplant experiment was retrieved in January 2004, bleaching was no longer evident and all of the transplanted corals had recovered their natural coloration. The nutrient enrichment 

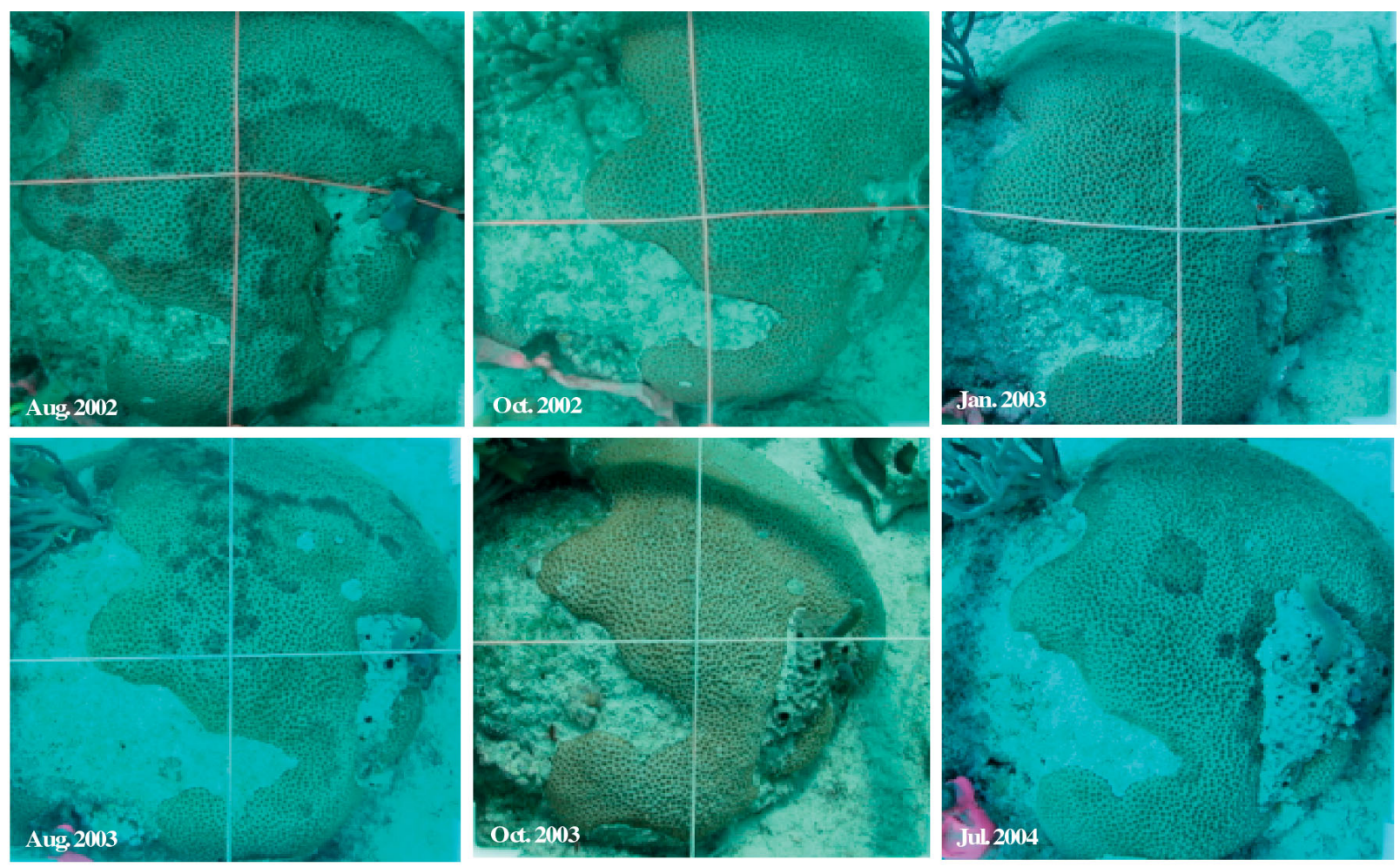

Fig. 4. Siderastrea siderea. Temporal variability in percent cover of DSS on a marked colony

did not cause an increased prevalence of DSS relative to controls as 1 of 5 colonies from each treatment became infected after 5 mo in the field (chi-squared test: $\chi^{2}=1.111, \mathrm{df}=1, \mathrm{p}=0.252$ ).

In the common garden experiment, there was no significant effect of site of origin on susceptibility to DSS. Only 2 colonies from Rainbow Gardens and Bock Wall and 1 colony from North Norman's became infected. None of the colonies from Whitehorse or Washing Machine became infected. Chi-squared tests indicated that none of these values are significant $\left(\chi^{2}=\right.$ 2.5, $\mathrm{df}=1, \mathrm{p}=0.114$ for Rainbow Gardens and Bock Wall; $\chi^{2}=1.111, \mathrm{df}=1, \mathrm{p}=0.252$ for North Norman's).

\section{Antimicrobial activity and chemical variability in Siderastrea siderea}

Crude extracts of Siderastrea siderea exhibited selective antimicrobial activity against 4 strains of gram-positive bacteria $(\mathrm{MS}=156.5, F=44.053, \mathrm{p}<$ 0.0001). Zones of inhibition of crude extracts were observed against 2 of the strains $(9.5 \pm 1.5$ and $14.5 \pm$ $3.5 \mathrm{~mm}$, respectively), whereas no zones of inhibition were observed against 2 other strains. Control discs did not exhibit antimicrobial activity.

Preliminary chemical fingerprints from the organic extracts of core samples from Siderastrea siderea produced 4 peaks of interest, which eluted at 29, 30, 32 and $33 \mathrm{~min}$, respectively (Fig. 7). Although there were many additional peaks, these were the most concentrated and represent the major components (totaling approx. $90 \%$ of the material) in the corals' organic extracts. All 4 peaks were present at different concentrations in healthy, diseased and control cores during different sampling periods (Fig. 8; MANOVA Wilks' Lambda, $F=8.007, \mathrm{p}<0.001$ for date, $F=5.229, \mathrm{p}=0.0001$ for condition), with a trend towards a significant interaction $(F=1.577, \mathrm{p}=$ 0.099). For each peak individually, there was a significant effect of date $(\mathrm{p}<0.05)$, and peaks 30 and 32 varied by condition ( $p=0.029$ for peak $30, p<0.0001$ for peak 32). Peak 29 was highest in January in all treatments; Peak 30 was lowest in January in all treatments, but both healthy and diseased cores from the diseased corals had greater concentrations than did controls; Peak 32 concentration was highest in control corals and increased over time, whereas concentrations from both cores in the diseased corals were slightly elevated in January; Peak 33 was absent in all treatments in January and in control cores in August. Note that most of the extract mass was in the water fraction; however, the presence of salt in that fraction has produced an experimental hurdle, and future studies will focus on constituents of the water extract. 

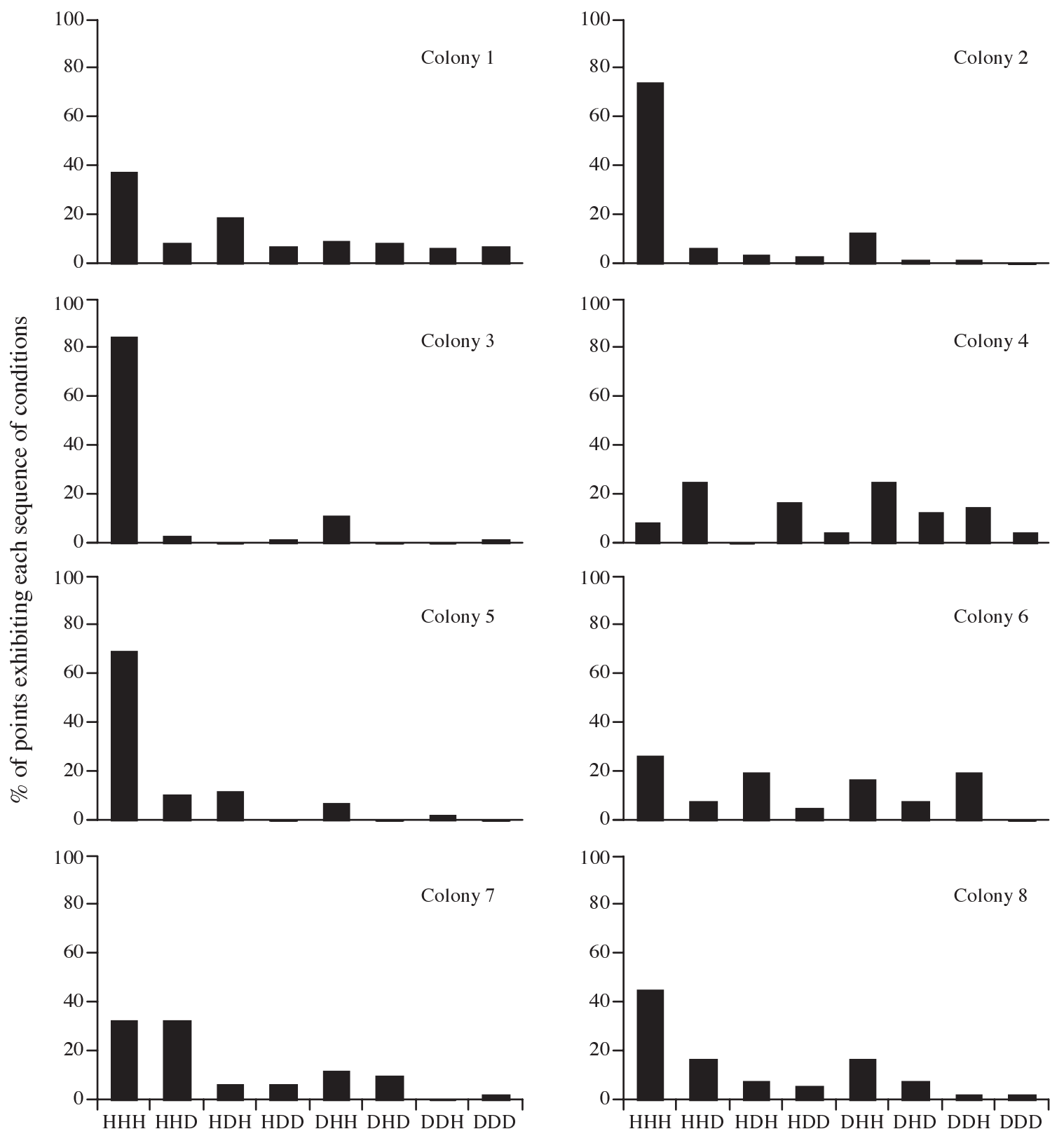

Fig. 5. Siderastrea siderea. Presence of DSS at individual points on 8 marked colonies in August 2002, August 2003 and July 2004. The sequence of letters $(\mathrm{H}=$ healthy, $\mathrm{D}=\mathrm{DSS}$ presence) represents the condition of individual points in each of 3 consecutive yr. Histograms above each sequence of letters indicate the percentage of points that fall into each category. Note that initially healthy points on colonies 2,3 and 5 were significantly more likely to remain healthy than to become diseased at subsequent dates, based on chi-squared analyses

\section{DISCUSSION}

In spite of their relatively pristine condition, the prevalence of coral diseases is high on the reefs near Lee Stocking Island, Exuma Cays, Bahamas. Although BBD, white plague type II, yellow band disease, and seasonal bleaching are not uncommon, DSS is by far the most prevalent disease affecting corals on these reefs, and Siderastrea siderea is the coral species most frequently affected at these sites. Other species exhibiting DSS (or DSS-like signs) in our surveys included: Agaricia agaricites, Colpophyllia natans, Diploria labyrinthiformis, Favia fragum, Montastraea annularis, M. cavernosa and Solenastrea hyades. GilAgudelo et al. (2004) suggested that DSS incidence was lower in the northern than in the central and southern Caribbean; however, the consistently high prevalence and persistence of DSS on these reefs in 


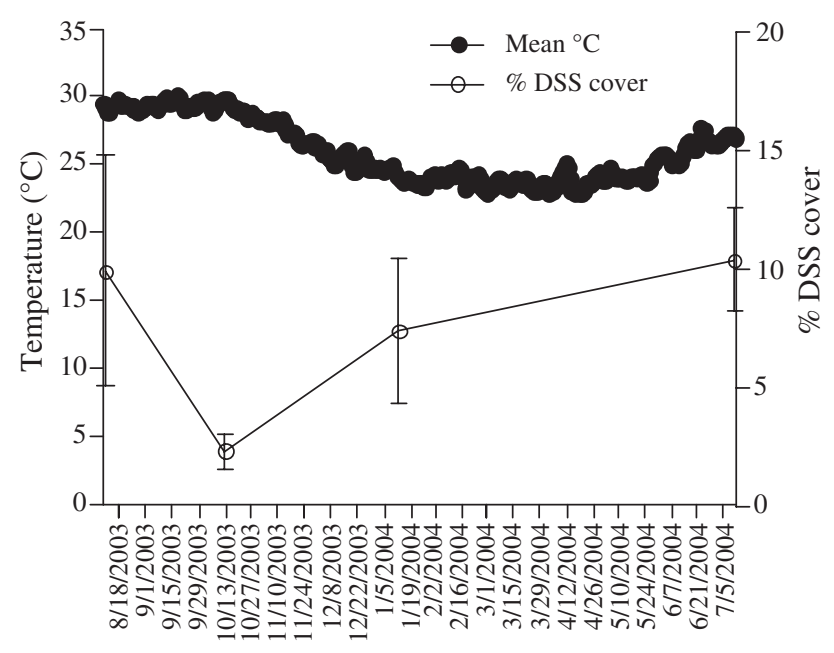

Fig. 6. Siderastrea siderea. Mean percent cover of DSS on marked diseased colonies and mean annual seawater temperature from a representative site near Lee Stocking Island, Exuma Cays, Bahamas. Dates $=\mathrm{mo} / \mathrm{d} / \mathrm{yr}$

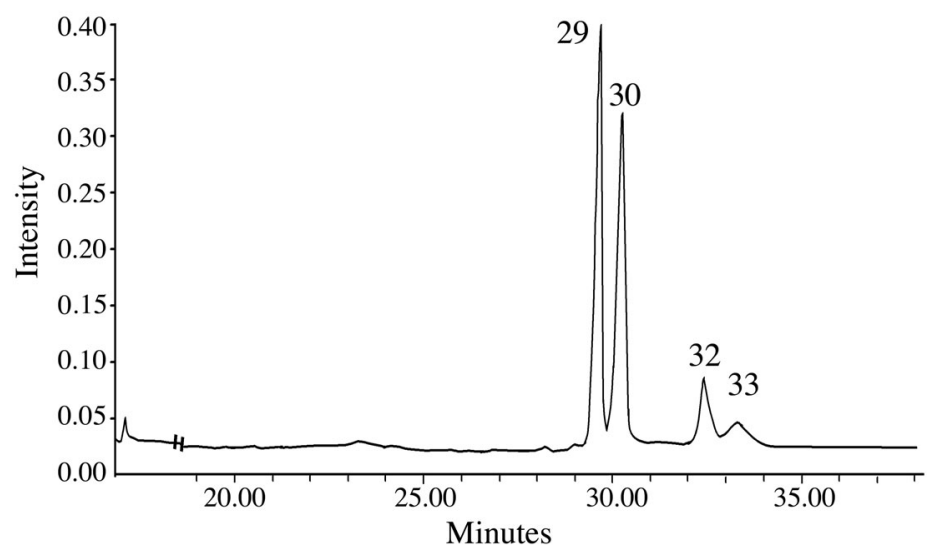

Fig. 7. Siderastrea siderea. Representative mass spectrum of the organic extract from a core sample

the central Bahamas indicates a more ubiquitous nature of this disease. In fact, when data from the present study are compared with similar surveys we conducted on the Belize barrier reef (March 2002 and 2003), in southeastern Puerto Rico (July 2002 and 2003), on Culebra (July 2003) and on St. Thomas (August 2004), we find that DSS prevalence on $S$. siderea ranges from 0 to $100 \%$ on any given reef at any point in time. Overall regional means range from $31.5 \%$ on St. Thomas in August 2004 to $50.3 \%$ on Culebra, Puerto Rico in July 2003. Garzon-Ferreira \& Gil (1998) reported similar levels of DSS in $S$. siderea in Colombia (12\% in 1994 and 1995, $28 \%$ in 1997), as did Cervino et al. (2001) for Bonaire (53\% in 1998), Turks \& Caicos (58\% in 1998) and Grenada (42\% in 1997) indicating widespread infection of $S$. siderea by DSS. Borger (2003) found that $100 \%$ of DSS infections in
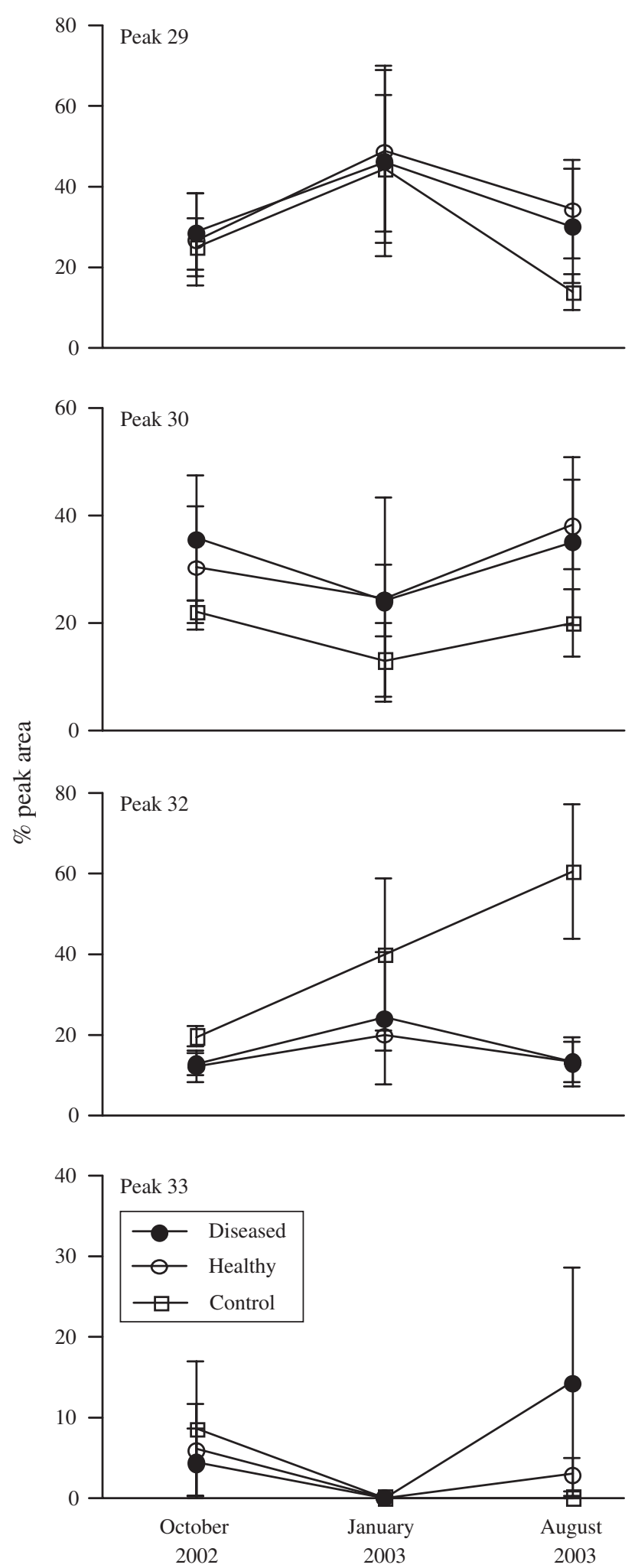

Fig. 8. Siderastrea siderea. Percent area under each peak from mass spectra of organic extracts from cores collected in October 2002, January 2003 and August 2003. Peak numbers refer to retention times (min) on high performance liquid chromatography mass spectrometry (HPLC/MS) 
Dominica in 2000 were on S. siderea, although she did not report the proportion of $S$. siderea colonies infected by the disease.

This is the first study to examine progression of DSS infections on individual colonies of Siderastrea siderea over multiple years. DSS on $S$. siderea exhibits a marked seasonality on both the population and individual colony scale on these reefs in the Bahamas (Figs. 2 \& 3). There was a significant decline in DSS prevalence at the population scale in October 2002 and 2003, which is mirrored by an almost complete disappearance of the infection on individual diseased colonies at those times (Figs. 3 \& 4). Unfortunately, DSS appears to rebound again by January of each year and remain high through the summer. There are significant interactions between coral condition and both date and reef, which result from the fact that percent cover of DSS increased on the control corals over time, and this effect was stronger on one of the monitored reefs than the other. Other studies reported a clumped distribution of DSS (Gil-Agudelo \& Garzon-Ferreira 2001, Borger 2003). However, the fact that the first DSS infection in our nearest neighbor control colonies did not occur until $8 \mathrm{mo}$ after we first identified those colonies suggests that proximity to infected colonies may not be an important factor in the spread of DSS. Dube et al. (2002) reported that aspergillosis is correlated with colony size in sea fans and Borger (2003) suggested that both DSS and BBD affected larger colonies of $S$. siderea more often than expected by chance. However, our data indicate that neither the probability of being infected with DSS, nor the degree of DSS infection, is related to colony size in $S$. siderea.

Individual points on colonies of Siderastrea siderea exhibited variability in their susceptibility to DSS through time. These points correspond to the polyplevel scale across the surface of a coral colony. On $63 \%$ of the colonies we followed, points that were initially healthy were equally likely to remain healthy or become diseased, while healthy points on the remaining $37 \%$ of colonies remained healthy. Thus, certain individuals within the population appear to have greater immunity and, potentially, fitness, although the mechanisms of this resistance are still unclear. These data are significant as they support genotypic, and potentially phenotypic, immunity within these corals. Some preliminary data suggest that endolithic fungi may be associated with DSS (G. Smith \& D. GilAgudelo pers. comm.); this clearly warrants further investigation. The results of our study suggest that the pathogenic organisms are localized within infected coral tissues and may represent a low-level chronic infection that flares up periodically, rather than an acute systemic infection that might kill entire colonies and affect the larger coral populations.
The seasonality of DSS on Siderastrea siderea on these reefs in the Bahamas does not appear to be directly associated with seawater temperature (Fig. 6). By contrast, earlier studies in Colombia suggested that DSS prevalence increased with increasing seawater temperature, peaking in September to November, when seawater temperature was highest, and declining when temperature was lowest (Garzón-Ferreira \& Gil 1998, GilAgudelo \& Garzon-Ferreira 2001). Borger (2003) found an increase in DSS infection from March to June, which coincided with a slight increase in seawater temperature. Similar to our findings, Gil-Agudelo \& Garzón-Ferreira (2001) also reported a dramatic decrease in DSS prevalence in October in 1 yr (1998) of their 2 yr study and suggested that this might be the result of an inability to detect the disease during a bleaching event at that time. This explanation seems unlikely, as a bleaching event was underway on our study reefs in October 2003, and remaining DSS infections were easy to detect. Santavy et al. (2001) did not find seasonality to be associated with overall mean percent coral disease based on spring and summer surveys in the Florida Keys. However, they suggested that there might be seasonality associated with certain diseases. Clearly, seasonal patterns will only be distinguished if surveys are performed frequently enough to identify such patterns.

Although our survey data indicated a high degree of variability in DSS prevalence in Siderastrea siderea by site, there was no consistent pattern. If each of our sites were to represent a separate population of S. siderea, one might expect differential susceptibility to DSS. This might be a reasonable assumption for some of our sites (e.g. Bock Wall is separated from all other sites by at least $2 \mathrm{~km}$ of deep water), but not for others (e.g. North Norman's and Rainbow Gardens are separated by approx. $500 \mathrm{~m}$ ). Nonetheless, there was no significant effect of site itself in our DSS surveys (Fig. 2), and our common garden experiment indicated that corals transplanted from each site to a single site, as well as back-transplants to that site, did not differ significantly in their susceptibility to DSS.

DSS prevalence in Siderastrea siderea was also not correlated with depth on our reefs in the Bahamas. GilAgudelo \& Garzón-Ferreira (2001) found that DSS was more prevalent in shallow depths $(<10 \mathrm{~m})$ when all coral species were considered, but also found no effect of depth on DSS prevalence in $S$. siderea. DSS was considered very rare at depths greater than $12 \mathrm{~m}$ (Garzon-Ferreira \& Gil 1998). However, the data from these earlier reports may have been confounded by the distribution patterns of the 2 most affected species, Montastraea annularis and $S$. siderea, which were more abundant in the shallow zones ( 0 to $6 \mathrm{~m}$ ) and were absent below $12 \mathrm{~m}$ (Gil-Agudelo \& Garzón-Ferreira 2001). In the present study, DSS prevalence was high- 
est on different reefs at different times, ranging from $81.25 \%$ on the deepest $(27 \mathrm{~m})$ forereef site in May 2002 to $66.67 \%$ on 1 of the shallowest $(5 \mathrm{~m})$ backreef sites in January 2003 (Fig. 2). S. siderea is commonly found at depths from 0 to $>30 \mathrm{~m}$ in the Exuma Cays.

Nutrient enrichment has been correlated with increased incidence of BBD (Bruckner et al. 1997, Kuta \& Richardson 2002), and increased severity of aspergillosis and yellow band disease (Bruno et al. 2003), and it is widely suggested that disease incidence increases with anthropogenic influence (reviewed by Sutherland et al. 2004). The results of our laboratory experiment suggest that nutrient enrichment does not affect DSS prevalence in Siderastrea siderea. However, the influence of bleaching may have impacted our results. Nonetheless, DSS prevalence on $S$. siderea is high even on the relatively pristine reefs of the Exuma Cays, as well as on reefs ranging from the inshore lagoon in La Parguera, Puerto Rico to those in marine reserves at Culebra and on offshore cays along the Belize barrier reef (D. J. Gochfeld \& M. Slattery unpubl.). Likewise, there was no correlation between DSS prevalence and human impacts in Colombia (GilAgudelo \& Garzón-Ferreira 2001).

Crude extracts of Siderastrea siderea demonstrated antimicrobial activity against 2 of 4 strains of ecologically relevant bacteria isolated from coral surfaces in the Bahamas, indicating that hard corals do possess chemical defenses against bacteria. Although these bacteria have not been identified, this selectivity is presumably adaptive, as some bacteria may be harmful to corals, whereas others may be beneficial or inconsequential (Knowlton \& Rohwer 2003, Kushmaro \& Kramarsky-Winter 2004). Koh (1997) tested extracts from 100 species of Australian scleractinian corals and found that $93 \%$ of extracts exhibited significant antimicrobial activity against the marine cyanobacterium Synechococcus sp., but only 2 coral extracts exhibited significant activity against marine bacteria, again indicating strong selectivity in chemical defenses against marine bacteria. Kelman (2004) tested extracts from 6 species of Red Sea corals against 11 marine bacteria and found all but 1 extract to exhibit selective, but very low levels of antibacterial activity.

Further investigation of the chemical defenses of Siderastrea siderea colonies over time indicates variability in these chemical defenses. Some compounds, such as HPLC Peaks 29 and 33 (Fig. 8), exhibit temporal variation in concentration, but this variation is unrelated to disease state, and therefore these compounds are probably not involved in antimicrobial defense. However, other compounds exhibit variability related to disease state. Although consistent in its temporal variability, Peak 30 was present in much lower concentrations in the control corals than in either the healthy or diseased cores from the diseased corals. By contrast, Peak 32 had a 3-fold higher concentration in control corals in August 2003, when DSS prevalence and cover were highest, suggesting a possible antimicrobial role for this compound. There was no significant difference in concentration of Peak 32 or any of these peaks between the healthy and diseased cores of the diseased corals, suggesting that at least these 4 compounds occur at systemic concentrations within individual colonies. Future studies will focus on identifying antimicrobial activity from additional chemical fractions and isolating active compounds from those fractions. This approach will be facilitated once the pathogen responsible for DSS has been isolated.

To date, there is little evidence that DSS causes extensive necrosis in affected corals (Borger 2003, GilAgudelo et al. 2004). Although DSS is clearly capable of causing tissue necrosis, we have not observed DSSrelated mortality at our study sites over $2 \mathrm{yr}$. It also does not appear that DSS caused a marked reduction in tissue regenerative ability of Siderastrea siderea, as previously suggested (Garces-Baquero 2000 cited in Gil-Agudelo et al. 2004); in almost every case, our coring scars were completely regenerated by the next sampling period (in some cases less than 2 mo). DSS in $S$. siderea clearly varies on a variety of spatial and temporal scales, but the mechanisms behind this variation have yet to be elucidated. Even at the smallest scales of variation, the colony and population levels, we have little insight into how one colony can be heavily affected by DSS whereas a nearby neighbor is unaffected, and how a colony that is heavily affected by DSS at one point in time, appears completely diseasefree shortly thereafter. There are multiple hypotheses that may explain these effects, one of which involves variability in the microbial communities to which these corals are exposed, and this is the subject of ongoing research by the authors. Additionally, genetic variability among hosts may result in differential susceptibility to disease, and this is also being addressed in ongoing studies. An alternative although not mutually exclusive hypothesis is that host colonies exhibit variability in resistance to disease. Potential mechanisms of resistance to disease in corals have recently been reviewed (Mullen et al. 2004, Sutherland et al. 2004); in light of the results of this study, future research must consider these issues. Additionally, the effects of DSS on fitness factors such as overall colony growth rates, and reproductive potential (Petes et al. 2003), still need to be investigated for this disease.

Acknowledgements. We thank the island staff at the Caribbean Marine Research Center for their support of this project, particularly T. Dahlgren, K. Buch, E. Rechisky and D. Smith. We thank the following students and collaborators for 
assistance in the field and laboratory: R. M. McCulloch, K. E. Marsh, L. Harrison, L. Wheeler, K. Rusk, B. Avery, P. Erwin and C. Frankfater. This study was funded by a University of Mississippi Faculty Small Grant to D.J.G., a Caribbean Marine Research Center grant to D.J.G. and M.S., and National Institute of Undersea Science and Technology grants to D.J.G. and J.B.O. The Caribbean Marine Research Center provided logistical support and facilities. Corals were collected under Bahamas Department of Fisheries permits \#MAF/FIS/1，12，17，46 ${ }^{\mathrm{A}}, 79$ and CITES permits \#2002/276, 2002/366, and 2003/142 issued by the Bahamas Department of Agriculture. This is contribution \#CMRC-02-NMRS-03-02A of the Caribbean Marine Research Center.

\section{LITERATURE CITED}

Alker AP, Smith GW, Kim K (2001) Characterization of Aspergillus sydowii (Thom et Church), a fungal pathogen of Caribbean sea fan corals. Hydrobiologia 460:105-111

Antonius A (1985) Coral diseases in the Indo-Pacific: a first record. PSZN I: Mar Ecol 6:197-218

Ben-Haim Y, Thompson FL, Thompson CC, Cnockaert MC, Hoste B, Swings J, Rosenberg E (2003) Vibrio coralliilyticus sp. nov, a temperature-dependent pathogen of the coral Pocillopora damicornis. Int J Syst Evol Microbiol 53: 309-315

Borger JL (2003) Three scleractinian coral diseases in Dominica, West Indies: distribution, infection patterns and contribution to coral tissue mortality. Rev Biol Trop 51(Suppl 4):25-38

Bruckner AW, Bruckner RJ, Williams EH Jr (1997) Spread of black-band diseases epizootic through the coral reef system in St. Ann's Bay, Jamaica. Bull Mar Sci 61:919-928

Bruno JF, Petes LE, Harvell CD, Hettinger A (2003) Nutrient enrichment can increase the severity of coral diseases. Ecol Lett 6:1056-1061

Button DK, Shut F, Quang P, Martin R, Robertson BR (1993) Viability and isolation of marine bacteria by dilution culture: theory, procedures, and initial results. Appl Environ Microbiol 59:881-891

Carey C (2000) Infectious disease and worldwide declines of amphibian populations, with comments on emerging diseases in coral reef organisms and in humans. Environ Health Perspect 108:143-150

Cervino JM, Goreau TJ, Nagelkerken I, Smith GW, Hayes R (2001) Yellow band and dark spot syndromes in Caribbean corals: distribution, rate of spread, cytology, and effects on abundance and division rate of zooxanthellae. Hydrobiologia 460:53-63

Cronin G, Hay ME (1996) Susceptibility to herbivores depends on recent history of both plant and animal. Ecology 77:1531-1543

Denner EBM, Smith GW, Busse HJ, Schumann P, Narzt T, Polson SW, Lubitz W, Richardson LL (2003) Aurantimonas coralicida gen. nov., sp. nov., the causative agent of white plague type II on Caribbean scleractinian corals. Int J Syst Evol Microbiol 53:1115-1122

Dube D, Kim K, Alker AP, Harvell CD (2002) Size structure and geographic variation in chemical resistance of sea fan corals Gorgonia ventalina to a fungal pathogen. Mar Ecol Prog Ser 231:139-150

Edmunds PJ (1991) Extent and effect of black band disease on a Caribbean reef. Coral Reefs 10:161-165

Garrison VH, Shinn EA, Foreman WT, Griffin DW and 6 others (2003) African and Asian dust: from desert soils to coral reefs. Bioscience 53:469-480
Garzón-Ferreira J, Gil DL (1998) Another unknown Caribbean coral phenomenon? Reef Encounter 24:10

Garzón-Ferreira J, Gil-Agudelo DL, Barrios LM, Zea S (2001) Stony coral diseases observed in southwestern Caribbean reefs. Hydrobiologia 460:65-69

Geiser DM, Taylor JW, Ritchie KB, Smith GW (1998) Cause of sea fan death in the West Indies. Nature 394:137-138

Gil-Agudelo DL, Garzón-Ferreira J (2001) Spatial and seasonal variation of dark spots disease in coral communities of the Santa Marta area (Columbian Caribbean). Bull Mar Sci 69:619-629

Gil-Agudelo DL, Smith GW, Garzón-Ferreira J, Weil E, Petersen D (2004) Dark spots disease and yellow band disease, two poorly known coral diseases with high incidence in Caribbean reefs. In: Rosenberg E, Loya Y (eds) Coral health and disease. Springer, Berlin, p 337-350

Gladfelter WB (1982) White-band disease in Acropora palmata: implications for the structure and growth of shallow reefs. Bull Mar Sci 32:639-643

Gochfeld DJ (1991) Energetics of a predator-prey interaction: corals and coral-feeding fishes. Pac Sci 45:246-256

Gochfeld DJ (1997) Mechanisms of coexistence between corals and coral-feeding butterflyfishes: territoriality, foraging behavior, and prey defense. PhD dissertation, University of Hawaii, Manoa

Goreau TJ, Cervino J, Goreau M, Hayes R and 14 others (1998) Rapid spread of diseases in Caribbean coral reefs. Rev Biol Trop 46 Suppl 5:157-171

Gram L, de Nys R, Maximilien R, Givskov M, Steinberg P, Kjelleberg $S$ (1996) Inhibitory effects of secondary metabolites from the red alga Delisea pulchra on swarming motility of Proteus mirabilis. Appl Environ Microbiol 62:4284-4288

Green EP, Bruckner AW (2000) The significance of coral disease epizootiology for coral reef conservation. Biol Conserv 96:347-361

Harvell CD, Kim K, Burkolder JM, Colwell RR and 9 others (1999) Emerging marine diseases: climate links and anthropogenic factors. Science 285:1505-1510

Harvell CD, Mitchell CE, Ward JR, Altizer S, Dobson AP, Ostfeld RS, Samuel MD (2002) Climate warming and disease risks for terrestrial and marine biota. Science 296: $2158-2162$

Hayes RL, Goreau NI (1998) The significance of emerging diseases in the tropical coral reef ecosystem. Rev Biol Trop 46 Suppl 5:173-185

Jensen PR, Harvell CD, Wirtz K, Fenical W (1996) Antimicrobial activity of extracts of Caribbean gorgonians. Mar Biol 125:411-419

Karban R, Baldwin IT (1997) Induced responses to herbivory. Chicago University Press, Chicago, IL

Kelman D (2004) Antimicrobial activity of sponges and corals. In: Rosenberg E, Loya Y (eds) Coral health and disease. Springer, Berlin, p 243-258

Kim K, Harvell CD, Kim PD, Smith GW, Merkel SM (2000a) Fungal disease resistance of Caribbean sea fan corals (Gorgonia spp.). Mar Biol 136:259-267

Kim K, Kim PD, Alker AP, Harvell CD (2000b) Chemical resistance of gorgonian corals against fungal infections. Mar Biol 137:393-401

Knowlton N, Rohwer F (2003) Multispecies microbial mutualisms on coral reefs: the host as a habitat. Am Nat 162: S51-S62

Koh EGL (1997) Do scleractinian corals engage in chemical warfare against microbes? J Chem Ecol 23:379-398

Kushmaro A, Kramarsky-Winter E (2004) Bacteria as a source of coral nutrition. In: Rosenberg E, Loya Y (eds) Coral health and disease. Springer, Berlin, p 231-242 
Kushmaro A, Banin E, Stackebrandt E, Rosenberg E (2001) Vibrio shiloi sp. nov: the causative agent of bleaching of the coral Oculina patagonica. Int J Syst Evol Microbiol 51: $1383-1388$

Kuta KG, Richardson LL (2002) Ecological aspects of black band disease of corals: relationships between disease incidence and environmental factors. Coral Reefs 21: 393-398

Lessios HA (1988) Mass mortality of Diadema antillarum in the Caribbean: What have we learned? Annu Rev Ecol Syst 19:371-393

McClintock JB, Baker BJ (2001) Marine chemical ecology. CRC Press, Boca Raton, FL

Mullen KM, Peters EC, Harvell CD (2004) Coral resistance to disease. In: Rosenberg E, Loya Y (eds) Coral health and disease. Springer, Berlin, p 377-399

Olson JB, Lord CC, McCarthy PJ (2000) Improved recoverability of microbial colonies from marine sponge samples. Microb Ecol 40:139-147

Patterson KL, Porter JW, Ritchie KB, Polson SW, Mueller E, Peters EC, Santavy DL, Smith GW (2002) The etiology of white pox, a lethal disease of the Caribbean elkhorn coral Acropora palmata. Proc Natl Acad Sci USA 99:8725-8730

Paul VJ (1992) Ecological roles of marine natural products. Cornell University Press, Ithaca, NY

Pawlik JR (1993) Marine invertebrate chemical defenses. Chem Rev 93:1911-1922

Peters EC (1993) Diseases of other invertebrate phyla: Porifera, Cnidaria, Ctenophora, Annelida, Echinodermata. In: Couch JA, Fournie JW (eds) Pathobiology of marine and estuarine organisms. CRC Press, Boca Raton, FL, p 393-449

Peters EC (1997) Diseases of coral-reef organisms. In: Birkeland C (ed) Life and death of coral reefs. Chapman \& Hall, New York, p 114-139

Petes LE, Harvell CD, Peters EC, Webb MAH, Mullen KM (2003) Pathogens compromise reproduction and induce melanization in Caribbean sea fans. Mar Ecol Prog Ser 264:167-171

Porter JW, Meier OW (1992) Quantification of loss and change in Floridian reef coral populations. Am Zool 32:625-640

Porter JW, Dustan P, Jaap WC, Patterson KL, Kosmynin V, Meier OW, Patterson ME, Parsons M (2001) Patterns of spread of coral diseases in the Florida Keys. Hydrobiologia 460:1-24

Richardson LL (1998) Coral diseases: What is really known? Trends Ecol Evol 13:438-443

Richardson LL (2004) Black band disease. In: Rosenberg E, Loya Y (eds) Coral health and disease. Springer, Berlin, p 325-336

Richardson LL, Goldberg WM, Kuta KG, Aronson RB and 5 others (1998) Florida's mystery coral-killer identified. Nature 392:557-558

Rosenberg E, Ben-Haim Y (2002) Microbial diseases of corals and global warming. Environ Microbiol 4:318-326

Rosenberg E, Loya Y (2004) Coral health and disease. Springer, Berlin

Submitted: September 15, 2004; Accepted: May 19, 2005
Rozenblat YBH, Rosenberg E (2004) Temperature-regulated bleaching and tissue lysis. In: Rosenberg E, Loya Y (eds) Coral health and disease. Springer, Berlin, p 303-324

Sammarco PW, Coll JC (1992) Chemical adaptations in the Octocorallia: evolutionary considerations. Mar Ecol Prog Ser 88:92-104

Santavy DL, Mueller E, Peters EC, MacLaughlin L, Porter JC, Patterson KL, Campbell J (2001) Quantitative assessment of coral diseases in the Florida Keys: strategy and methodology. Hydrobiologia 460:39-52

Shinn EA, Smith GW, Prospero JM, Betzer P, Hayes ML, Garrison VH, Barber RT (2000) African dust and the demise of Caribbean coral reefs. Geol Res Lett 27:3029-3032

Slattery M (1999) Fungal pathogenesis of the sea fan Gorgonia ventalina: direct and indirect consequences. Chemoecol 9:97-104

Slattery M, Hamann MT, McClintock JB, Perry TL, Puglisi MP, Yoshida WY (1997) Ecological roles for water-borne metabolites from Antarctic soft corals. Mar Ecol Prog Ser 161:133-144

Slattery M, Rajbhandari I, Wesson K (2001) Competitionmediated antibiotic induction in the marine bacterium Streptomyces tenjimariensis. Microb Ecol 41:90-96

Smith GW, Weil E (2004) Aspergillosis of gorgonians. In: Rosenberg E, Loya Y (eds) Coral health and disease. Springer, Berlin, p 279-287

Sutherland KP, Ritchie KB (2004) White pox disease of the Caribbean elkhorn coral, Acropora palmata. In: Rosenberg E, Loya Y (eds) Coral health and disease. Springer, Berlin, p 289-300

Sutherland KP, Porter JW, Torres C (2004) Disease and immunity in Caribbean and Indo-Pacific zooxanthellate corals. Mar Ecol Prog Ser 266:273-302

Taylor DL (1983) The black band disease of Atlantic reef corals. II. Isolation, cultivation, and growth of Phormidium corallyticum. PSZN I: Mar Ecol 4:321-328

Tollrian R, Harvell CD (1999) The ecology and evolution of inducible defenses. Princeton University Press, Princeton, NJ

Toren A, Landau L, Kushmaro A, Loya Y, Rosenberg E (1998) Effect of temperature on adhesion of Vibrio strain AK-1 to Oculina patagonica and on coral bleaching. Appl Environ Microbiol 64:1379-1384

Wahl M, Jensen PR, Fenical W (1994) Chemical control of bacterial epibiosis on ascidians. Mar Ecol Prog Ser 110: $45-57$

Walls JT, Ritz DA, Blackman AJ (1993) Fouling, surface bacteria and antibacterial agents of four bryozoan species found in Tasmania, Australia. J Exp Mar Biol Ecol 169: $1-13$

Weil E (2004) Coral reef diseases in the wider Caribbean. In: Rosenberg E, Loya Y (eds) Coral health and disease. Springer, Berlin, p 35-68

Weil E, Urreiztieta I, Garzon-Ferreira J (2000) Geographic variability in the incidence of coral and octocoral diseases in the wider Caribbean. Proc 9th Int Coral Reef Symp 2: 1231-1237

Proofs received from author(s): January 27, 2006 